\title{
Quality of routine essential care during childbirth: clinical observations of uncomplicated births in Uttar Pradesh, India
}

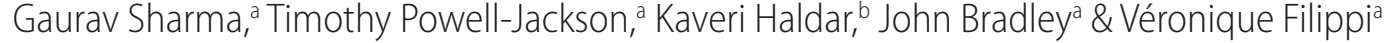

\begin{abstract}
Objective To evaluate the quality of essential care during normal labour and childbirth in maternity facilities in Uttar Pradesh, India. Methods Between 26 May and 8 July 2015, we used clinical observations to assess care provision for 275 mother-neonate pairs at 26 hospitals. Data on 42 items of care were collected, summarized into 17 clinical practices and three aggregate scores and then weighted to obtain population-based estimates. We examined unadjusted differences in quality between the public and private facilities. Multilevel linear mixed-effects models were used to adjust for birth attendant, facility and maternal characteristics.

Findings The quality of care we observed was generally poor in both private and public facilities; the mean percentage of essential clinical care practices completed for each woman was $35.7 \%$. Weighted estimates indicate that unqualified personnel provided care for $73.0 \%$ and $27.0 \%$ of the mother-neonate pairs in public and private facilities, respectively. Obstetric, neonatal and overall care at birth appeared better in the private facilities than in the public ones. In the adjusted analysis, the score for overall quality of care in private facilities was found to be six percentage points higher than the corresponding score for public facilities.

Conclusion In 2015, the personnel providing labour and childbirth care in maternity facilities were often unqualified and adherence to care protocols was generally poor. Initiatives to measure and improve the quality of care during labour and childbirth need to be developed in the private and public facilities in Uttar Pradesh.
\end{abstract}

Abstracts in عربي, 中文, Français, Русский and Español at the end of each article.

\section{Introduction}

The quality of care offered at maternity facilities not only affects pregnant women - both emotionally and physically - but also has an impact on the long-term health and survival of mothers and neonates. ${ }^{1,2}$ An increased focus on care during childbirth can lead to reductions in disability, maternal and neonatal mortality and stillbirths., ${ }^{2,3}$

An estimated $72 \%$ of all deliveries - including $69 \%$ of those in South Asia - now occur in health facilities. ${ }^{4}$ Even in health facilities, however, failures in the processes of care can result in bad obstetric and neonatal outcomes ${ }^{5,6}$ and care of poor quality often leads to low demand for maternal health services. ${ }^{7,8}$ Some routine interventions can be ineffective or even harmful. ${ }^{9}$

Despite substantial efforts to promote evidence-based obstetrics, the uptake of recommended interventions into clinical practice has been limited. ${ }^{10-12}$ Clinical practices can be difficult to change because they are influenced by health worker and patient characteristics, the complexity of the tasks involved and the institutional and sociocultural environments. ${ }^{13,14}$

In 2015, the estimated number of maternal deaths in India was higher than that in any other country apart from Nigeria. ${ }^{15}$ India has to make rapid improvements in its levels of maternal mortality if the Global Strategy for Women's, Children's and Adolescents' Health's targets are to be met by $2030 .{ }^{16}$ Maternity services in India are available from an enormous range of health providers. Maternity care in the public sector is provided through a network of primary, secondary and tertiary facilities that, in principle, provide routine care, basic emergency obstetric care and comprehensive emergency obstetric care, respectively. ${ }^{17}$ In the private sector, maternity care is provided by a heterogeneous collec- tion of facilities that range from small maternity homes to large multispecialty medical colleges and tertiary hospitals.

An analysis of the results of Demographic and Health Surveys conducted in 57 countries between 2000 and 2013 revealed that, in the various regions of the world, the private sector accounted for $9-56 \%$ of deliveries. ${ }^{18}$ In 2003-2005, an estimated $22 \%$ of all deliveries in India occurred in the private sector. ${ }^{19}$ Among Indian women, previous negative pregnancy outcomes and relatively high socioeconomic status are positively associated with use of private facilities ${ }^{19}$ whereas belonging to a so-called scheduled caste or tribe is negatively associated with such use. ${ }^{20}$ The private sector is more expensive than the public sector but most Indians associate the private sector with better amenities and a higher standard of care. ${ }^{20}$

Although much information exists on the quality of emergency obstetric care in India, ${ }^{21,22}$ there appears to have been little research on the quality of normal labour and childbirth care, particularly in private facilities. The results of a few relevant qualitative studies on the public sector have generally revealed care of poor quality, often characterized by high rates of labour augmentation, routine episiotomies, no choice of position, non-adherence to protocols, limited monitoring, early discharge from the hospital and poor neonatal care. ${ }^{23-25}$ In most areas of the world, deliveries in the private sector are much more likely to be by caesarean section than deliveries in the public sector. ${ }^{26-29}$ This paper reports findings from clinical observations that were used to describe and investigate the quality of care provided routinely, for uncomplicated labour and childbirth, in maternity facilities in Uttar Pradesh, India.

\section{Methods \\ Study setting}

This study was conducted in three districts of Uttar Pradesh: Kannauj, Kanpur Dehat and Kanpur Nagar. ${ }^{30}$ In 2012-2013,

\footnotetext{
a London School of Hygiene \& Tropical Medicine, Keppel Street, London, WC1E 7HT, England.

b Sambodhi Research and Communications, New Delhi, India.

Correspondence to Gaurav Sharma (email: drsharmag@gmail.com).

(Submitted: 14 June 2016 - Revised version received: 30 December 2016 - Accepted: 3 January 2017 - Published online: 24 April 2017)
} 
Uttar Pradesh was the Indian state with the largest population and the second and third highest levels of maternal and neonatal mortality, respectively. ${ }^{31}$ At this time, the estimated number of neonatal deaths per 1000 live births was 55 deaths in Kannauj, 41 deaths in Kanpur Dehat and 24 deaths in Kanpur Nagar. The estimated percentage of deliveries occurring in public and private facilities, respectively, was $43 \%$ and $15 \%$ in Kannauj, $46 \%$ and $10 \%$ in Kanpur Dehat, and $34 \%$ and $34 \%$ in Kanpur Nagar. ${ }^{31}$ Also widespread inequities across the continuum of care existed - in terms of the recorded indicators of maternal, neonatal and reproductive health - in the three study districts. ${ }^{31}$

\section{Sampling}

We used a multistage sampling method. The initial sampling frame included 59 facilities in Uttar Pradesh that provided maternity services: all 29 of the larger public facilities listed by the Indian Department of Health - i.e. facilities that reported at least 200 deliveries per month $^{32}$ and, in theory, provided basic emergency obstetric care at all hours of the day and night - plus the 30 private facilities that, in theory, provided continuous maternity care. The private facilities were identified by key informants from Sambodhi Research and Communications (Lucknow, India) - an organization that has worked in health research in the study districts for several years.

In the second stage of sampling, we attempted to select six public facilities per district - i.e. a random selection of four of the community health centres, one of the medical colleges and one of the district hospitals. Since Kanpur Dehat did not have a medical college, we had to select an additional district hospital. Although we invited the 18 selected public facilities and all 30 private facilities to participate in our study, 13 facilities - all private - refused to participate. At nine of the facilities that agreed to participate - again all from the private sector - no deliveries occurred while observers were present. The observational data that we analysed therefore came from 18 public facilities and eight private (Fig. 1). Power calculations were used to estimate the number of observations required at each facility (available from the corresponding author). We expected observations of up to 10 deliveries to be completed either over the two days of observation at each public facility or over the week of observation at each private facility. The 211 observed deliveries from 18 public sector facilities are a sample of an estimated 41512 annual deliveries that occurred in 18 public sector facilities in 2015. The 64 observed deliveries from eight private sector facilities represented 3579 deliveries from 8 private sector facilities in 2015. These data on annual caseloads were self-reported by health facilities and collected by us during the study. The larger household survey in three study districts found that public sector deliveries account for $54.8 \%(n=1943)$, private sector account for $13.7 \%(n=486)$ and home deliveries account for $31.5 \%(n=1117)$ annually. The public sector was found to be 3.98 times larger than the private sector. Therefore, to get a representative sample of births by health facility, we multiplied the private sector births by a factor of 2.94 to get a total of 10535 .

\section{Fig. 1. Flowchart showing the selection and investigation of participants for the study of the quality of maternal and neonatal care at birth, Uttar Pradesh, India, 2015}

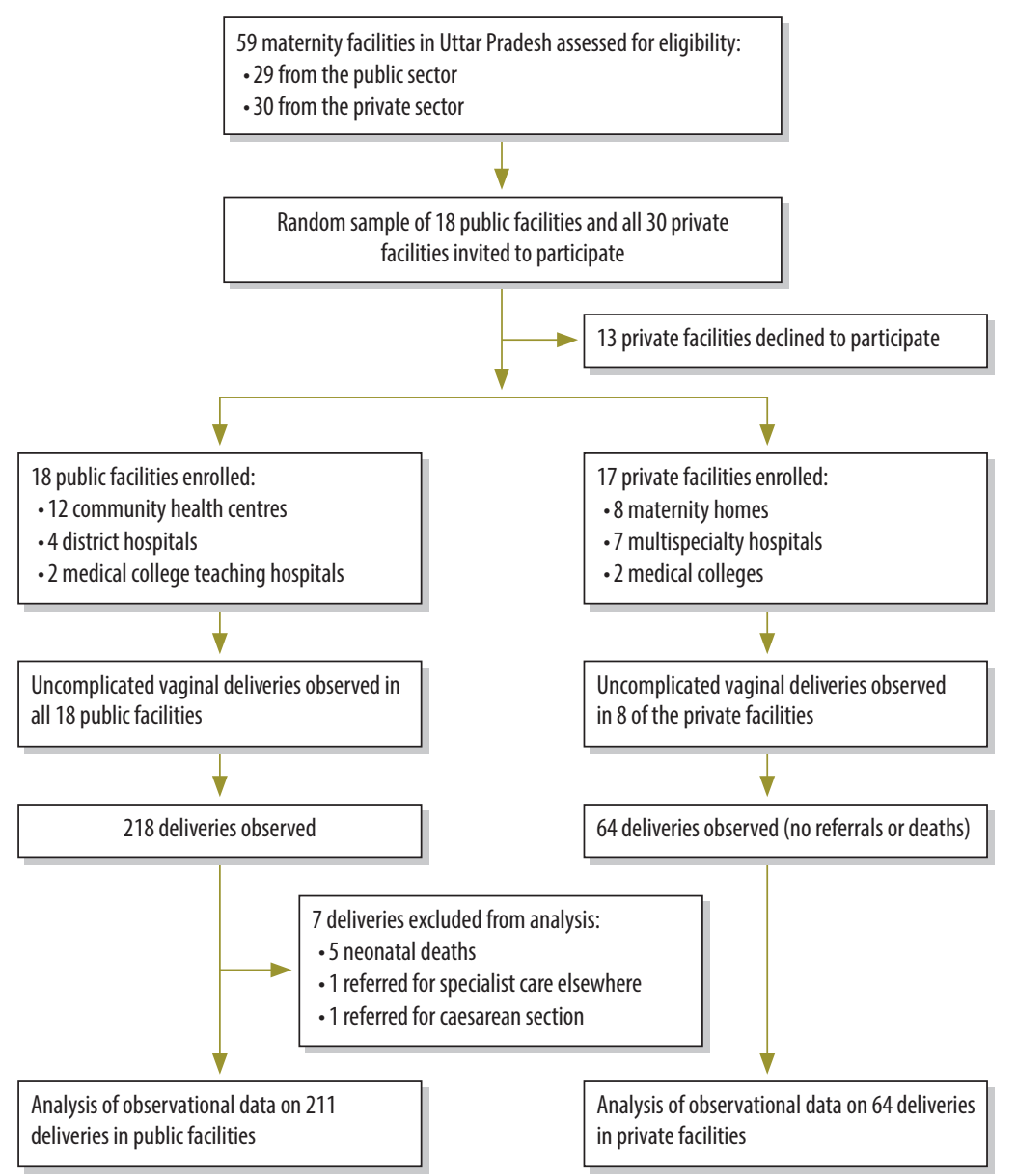


Table 1. Framework used for the assessment of essential care at birth, India, 2015

\begin{tabular}{|c|c|c|c|c|}
\hline \multirow[t]{2}{*}{ Timing } & \multicolumn{2}{|r|}{ Obstetric care } & \multicolumn{2}{|c|}{ Fetal or neonatal care } \\
\hline & Clinical practice & Observed items & Clinical practice & Observed items \\
\hline \multirow[t]{3}{*}{$\begin{array}{l}\text { On admission and } \\
\text { during first stage } \\
\text { of labour }\end{array}$} & $\begin{array}{l}\text { Regular monitoring } \\
\text { of labour using a } \\
\text { partograph }\end{array}$ & $\begin{array}{l}\text { Is labour monitored regularly with } \\
\text { partograph? }\end{array}$ & $\begin{array}{l}\text { Check fundal } \\
\text { height and fetal } \\
\text { presentation }\end{array}$ & $\begin{array}{l}\text { Is fundal height checked } \\
\text { and is fetal presentation } \\
\text { checked? }\end{array}$ \\
\hline & $\begin{array}{l}\text { Measures for the } \\
\text { prevention of } \\
\text { maternal infection } \\
\text { during admission }\end{array}$ & $\begin{array}{l}\text { Are hands washed before examination and } \\
\text { are sterile gloves put on before vaginal } \\
\text { examination? }\end{array}$ & $\begin{array}{l}\text { Regular monitoring } \\
\text { of fetal heart rate }\end{array}$ & $\begin{array}{l}\text { Is fetal heart rate monitored } \\
\text { at regular intervals? }\end{array}$ \\
\hline & $\begin{array}{l}\text { Screening for } \\
\text { pre-eclampsia and } \\
\text { eclampsia }\end{array}$ & $\begin{array}{l}\text { Is blood pressure monitored and urine } \\
\text { tested for proteins? }\end{array}$ & & \\
\hline \multirow[t]{7}{*}{$\begin{array}{l}\text { From second } \\
\text { stage of labour } \\
\text { to completion of } \\
\text { childbirth }\end{array}$} & $\begin{array}{l}\text { Measures for the } \\
\text { prevention of } \\
\text { maternal infection } \\
\text { during childbirth }\end{array}$ & $\begin{array}{l}\text { Are sterile gloves put on before vaginal } \\
\text { examination and are vulva and perineum } \\
\text { cleaned with antiseptic? }\end{array}$ & $\begin{array}{l}\text { Health workers } \\
\text { prepared for } \\
\text { resuscitation if } \\
\text { required }\end{array}$ & $\begin{array}{l}\text { Is ventilation bag available } \\
\text { and is neonatal mask } \\
\text { available and laid out? }\end{array}$ \\
\hline & $\begin{array}{l}\text { Active } \\
\text { management of } \\
\text { the third stage of } \\
\text { labour }\end{array}$ & $\begin{array}{l}\text { Is uterotonic given within minute of birth, } \\
\text { is the cord clamped and is there controlled } \\
\text { cord traction? }\end{array}$ & Neonatal cord care & $\begin{array}{l}\text { Is cord cut with a sterile } \\
\text { instrument? }\end{array}$ \\
\hline & $\begin{array}{l}\text { Assessment of } \\
\text { maternal blood loss }\end{array}$ & $\begin{array}{l}\text { Are the placenta and membranes checked } \\
\text { for completeness, is the vagina checked for } \\
\text { tears and is there monitoring of bleeding } \\
\text { postpartum? }\end{array}$ & $\begin{array}{l}\text { Appropriate } \\
\text { thermal care of } \\
\text { neonate }\end{array}$ & $\begin{array}{l}\text { Is neonate dried properly; } \\
\text { is skin-to-skin contact } \\
\text { between neonate and } \\
\text { mother initiated and is the } \\
\text { neonate covered with a dry } \\
\text { towel? }\end{array}$ \\
\hline & \multirow[t]{2}{*}{$\begin{array}{l}\text { Use of woman- } \\
\text { centred respectful } \\
\text { care practices }\end{array}$} & \multirow{2}{*}{$\begin{array}{l}\text { Is process of labour explained to the } \\
\text { mother or support person at least once, is } \\
\text { companion allowed to be with the mother } \\
\text { during labour, is mother informed before } \\
\text { vaginal examination, is visual privacy } \\
\text { ensured and is mother asked about choice } \\
\text { of position? }\end{array}$} & $\begin{array}{l}\text { Assessment of } \\
\text { Apgar score }\end{array}$ & $\begin{array}{l}\text { Is the Apgar score assessed } \\
\text { one minute after birth and is } \\
\text { it assessed five minutes after } \\
\text { birth? }\end{array}$ \\
\hline & & & $\begin{array}{l}\text { Initiation of early } \\
\text { breastfeeding }\end{array}$ & $\begin{array}{l}\text { Did the mother initiate } \\
\text { breastfeeding within hour } \\
\text { of birth? }\end{array}$ \\
\hline & $\begin{array}{l}\text { Avoidance } \\
\text { of harmful or } \\
\text { unnecessary } \\
\text { interventions for } \\
\text { mother }\end{array}$ & $\begin{array}{l}\text { Is an enema given, is the pubic area shaved, } \\
\text { is fundal pressure applied to hasten delivery } \\
\text { of baby or placenta, is there uterine lavage } \\
\text { after delivery, is there manual exploration of } \\
\text { the uterus after delivery and is there use of } \\
\text { episiotomy without any indication? }\end{array}$ & $\begin{array}{l}\text { Avoidance } \\
\text { of harmful or } \\
\text { unnecessary } \\
\text { practices for } \\
\text { neonate }\end{array}$ & $\begin{array}{l}\text { Is their routine aspiration } \\
\text { of neonate's nose, is the } \\
\text { neonate slapped and is the } \\
\text { neonate held upside down? }\end{array}$ \\
\hline & $\begin{array}{l}\text { Avoidance } \\
\text { of harmful or } \\
\text { unnecessary health } \\
\text { worker behaviour }\end{array}$ & $\begin{array}{l}\text { Does the health worker restrict mother's } \\
\text { fluid and food intake during labour; do they } \\
\text { insult, shout or threaten the mother during } \\
\text { labour and childbirth; and, do they hit, } \\
\text { pinch or slap the mother during labour and } \\
\text { childbirth? }\end{array}$ & & \\
\hline
\end{tabular}

Note: We assessed nine obstetric care and eight neonatal care practices.

enumerators with a clinical background visited the admissions, emergency, labour and postnatal wards to identify pregnant women who were likely to undergo uncomplicated vaginal births. Two enumerators were then stationed at each facility for either two days - if the facility was in the public sector - or a week - if the facility was in the private sector - and they observed round-theclock provision of care for mothers and their neonates. Data were collected between 26 May and 8 July 2015.

\section{Ethics}

We obtained ethical approval from the Ethics Review Board of the Public Healthcare Society and the Indian Council for Medical Research in India, and the London School of Hygiene \& Tropical Medicine in the United Kingdom of Great Britain and Northern Ireland.

\section{Measures}

Learning from previous quality measurement efforts, ${ }^{36,37}$ our assessments of quality of care encompassed not only the provision of clinical care but also clients' experiences of care. We investigated both the application of evidence-based practices - including use of potentially harmful interventions - and womancentred respectful care practices during the birthing process. ${ }^{38}$ We collected data on 42 items of care for each observation (Table 1). Each item was coded 1 if completed and 0 if not. We then aggregated the items into 17 care practices - i.e. nine obstetric and eight neonatal - and 
scored each practice 1 if fully completed and 0 if not (Table 1). Some practices were based on a single item and some were based on multiple items. Finally, summary scores for obstetric care, neonatal care and overall essential care at birth - based on the relevant nine, relevant eight and all 17 clinical practices, respectively - were calculated as the percentage of the practices measured that were completed for each woman.

For each woman investigated, data on household ownership of a common set of assets were collected and then used, in principal components analysis, to generate quintiles of wealth status. ${ }^{39}$ We recorded the age, caste, day and time of admission, parity, referral status and wealth quintile of each woman, whether the birth attendants were qualified or unqualified and the facilities' maternity caseloads - i.e. the numbers of deliveries recorded in 2014.

\section{Analysis}

Descriptive analyses were carried out at the level of individual women. We used the svy command in Stata version 14 (StataCorp. LP, College Station, United States of America) to account for clus- tering and to incorporate weights based on each facility's maternity caseload. All of the percentages shown in the Results section are weighted estimates. Frequencies, means, prevalence and proportions were calculated for covariates disaggregated by sector. A two-level linear mixed-effects model was used - with a random effect at the facility level to account for clustering. ${ }^{40}$ The exposure variable was public or private sector. The explanatory variables were the birth attendant's and women's characteristics and the maternity caseloads that we had recorded and - to reduce the effects of

\section{Table 2. Characteristics of pregnant women with uncomplicated births investigated in public and private maternity facilities, Uttar Pradesh, India, 2015}

\begin{tabular}{|c|c|c|c|c|c|c|c|}
\hline \multirow[t]{2}{*}{ Characteristic } & \multicolumn{3}{|c|}{ Unweighted numbers (\%) } & \multicolumn{3}{|c|}{ Weighted percentages ${ }^{a}$} & \multirow[t]{2}{*}{$p^{b}$} \\
\hline & $\begin{array}{c}\text { Total } \\
(n=275)\end{array}$ & $\begin{array}{c}\text { Public } \\
(n=211)\end{array}$ & $\begin{array}{l}\text { Private } \\
(n=64)\end{array}$ & $\begin{array}{c}\text { Total } \\
(n=52047)\end{array}$ & $\begin{array}{c}\text { Public } \\
(n=41512)\end{array}$ & $\begin{array}{c}\text { Private } \\
(n=10535)\end{array}$ & \\
\hline Age in years & & & & & & & 0.85 \\
\hline$<20$ & $16(5.8)$ & $12(5.6)$ & $4(6.2)$ & 5.5 & 5.7 & 4.4 & \\
\hline 20 to 34 & $247(89.8)$ & $191(90.5)$ & $56(87.5)$ & 90.4 & 90.4 & 90.5 & \\
\hline$\geq 35$ & $12(4.3)$ & $8(3.7)$ & $4(6.2)$ & 4.1 & 3.8 & 5.1 & \\
\hline Parity & & & & & & & 0.3 \\
\hline Primipara & $119(43.2)$ & $90(42.6)$ & $29(45.3)$ & 44.0 & 41.6 & 53.4 & \\
\hline Multipara & $156(56.7)$ & $121(57.3)$ & $35(54.7)$ & 56.0 & 58.4 & 46.6 & \\
\hline Referral status & & & & & & & 0.003 \\
\hline Came directly to study facility & $243(88.4)$ & $197(93.4)$ & $46(71.9)$ & 91.5 & 95.9 & 74.1 & \\
\hline Referred from another facility & $32(11.6)$ & $14(6.6)$ & $18(28.1)$ & 8.5 & 4.0 & 25.9 & \\
\hline Caste category & & & & & & & 0.002 \\
\hline Scheduled caste & $59(21.4)$ & $53(25.1)$ & $6(9.4)$ & 24.2 & 28.7 & 6.4 & \\
\hline Scheduled tribe & $2(0.7)$ & $0(0.0)$ & $2(3.1)$ & 0.3 & 0.0 & 1.4 & \\
\hline Other backward caste & $153(55.6)$ & $111(52.6)$ & $42(65.6)$ & 51.4 & 48.9 & 61.1 & \\
\hline General caste & $61(22.2)$ & $47(22.3)$ & $14(21.8)$ & 24.1 & 22.3 & 31.0 & \\
\hline Wealth quintile & & & & & & & 0.07 \\
\hline First (poorest) & $56(20.4)$ & $49(23.2)$ & $7(11.0)$ & 22.5 & 24.2 & 15.9 & \\
\hline Second & $54(19.6)$ & $46(21.8)$ & $8(12.5)$ & 17.7 & 19.5 & 10.6 & \\
\hline Third & $55(20.0)$ & $36(17.0)$ & 19 (29.6) & 17.7 & 17.6 & 18.2 & \\
\hline Fourth & $55(20.0)$ & $46(21.8)$ & $9(14.0)$ & 19.5 & 21.9 & 9.9 & \\
\hline Fifth (wealthiest) & $55(20.0)$ & $34(16.1)$ & $21(32.8)$ & 22.5 & 16.7 & 45.3 & \\
\hline Type of birth attendant & & & & & & & 0.01 \\
\hline Qualified & $113(41.1)$ & 75 (35.5) & $38(59.4)$ & 36.2 & 27.0 & 73.0 & \\
\hline Unqualified $^{d}$ & $162(58.9)$ & $136(64.5)$ & $26(40.6)$ & 63.8 & 73.0 & 27.0 & \\
\hline Timing of admission & & & & & & & 0.003 \\
\hline Within daytime work-hours ${ }^{\mathrm{e}}$ & $254(92.3)$ & $191(90.5)$ & $63(98.4)$ & 94.4 & 93.1 & 99.5 & \\
\hline Out of hours & $21(7.6)$ & $20(9.5)$ & $1(1.5)$ & 5.5 & 6.9 & 0.5 & \\
\hline Admission day & & & & & & & 0.58 \\
\hline Weekday & $211(76.7)$ & $158(74.8)$ & $53(82.8)$ & 77.2 & 75.9 & 81.9 & \\
\hline Saturday or Sunday & $64(23.3)$ & $53(25.1)$ & $11(17.1)$ & 22.8 & 24.0 & 18.1 & \\
\hline
\end{tabular}

Weighted according to the reported maternity caseload of the study facilities in 2014.

${ }^{b}$ For the comparison of the weighted percentages for the private sector with the corresponding values for the private sector.

Doctors, nurses or nurse-midwives - with at least 5, 4 and 2 years of pre-service training, respectively - who are licensed, regulated and endorsed by the government to provide maternity care at health facilities.

Accredited social health activists, cleaners, hospital porters, other community health workers, traditional birth attendants and others who are not legally allowed by the government to provide maternity care at health facilities.

That is, between 09:00 and 17:00. 


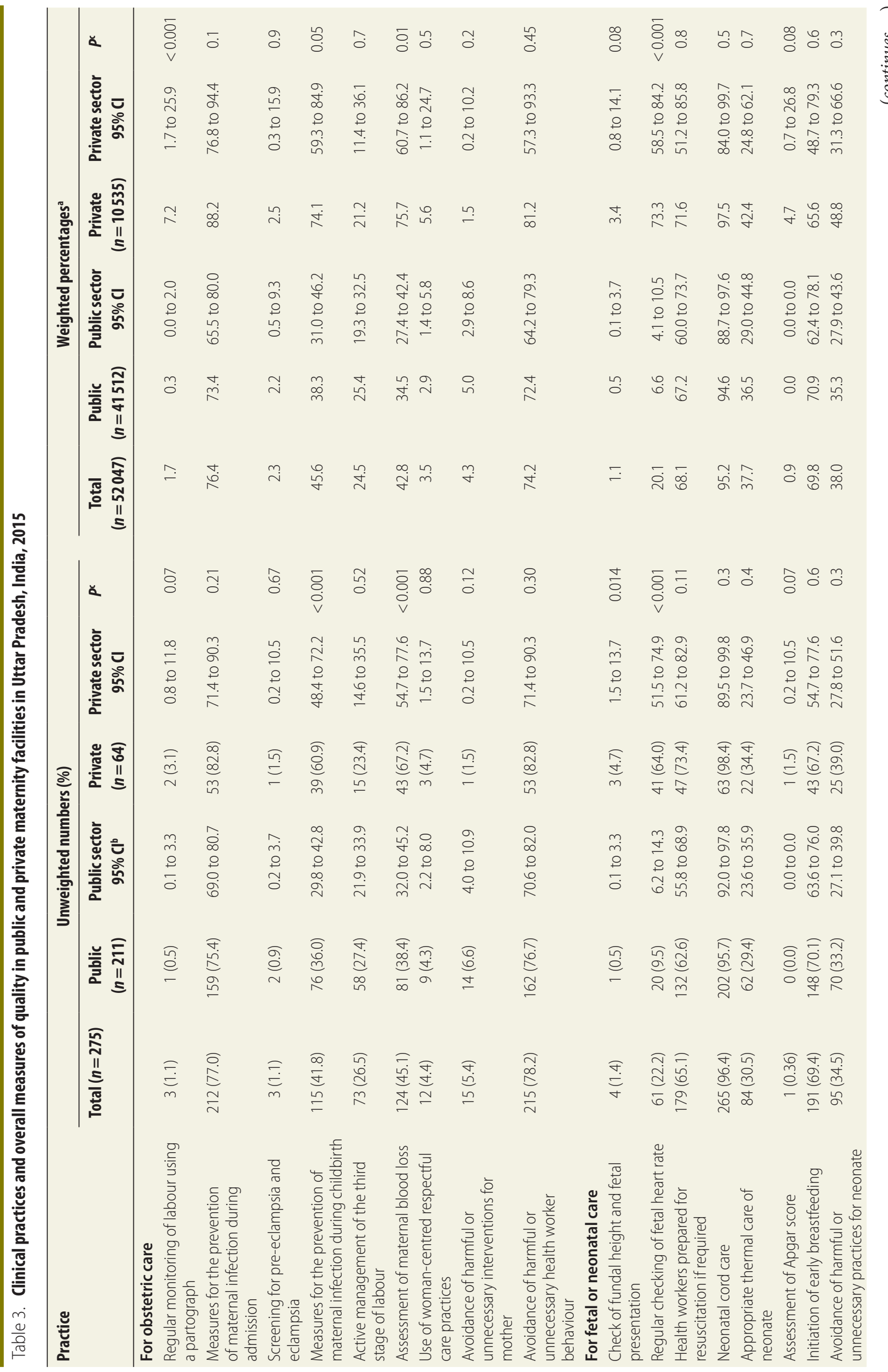




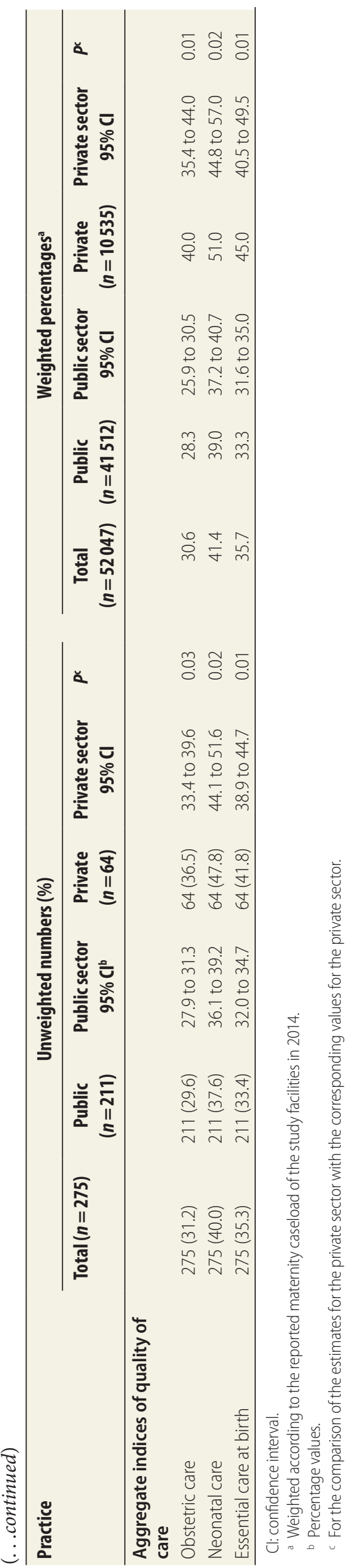

any inter-observer bias - a dummy variable for each enumerator. Estimation was by restricted maximum likelihood. We used a Wald test to generate an overall $P$-value for each categorical variable e.g. age group - and assess whether there was a significant association between a given explanatory variable and the quality of care that had been observed.

\section{Results}

\section{Sample characteristics}

Of the 275 observations, 211 were conducted in public facilities and most pregnant women had come directly to the study facilities $(91.5 \%)$, were 20 to 34 years of age $(90.4 \%)$, multiparous (56.0\%) and belonged to the caste category known as 'other backward' (51.4\%; Table 2). Compared with those in the public sector, higher proportions of pregnant women in the private sector belonged to the caste category known as 'other backward' $(P=0.002)$ and although not statistically significant - to the wealthiest quintile $(P=0.07)$ (Table 2). According to the weighted estimates, qualified personnel performed $73.0 \%$ of deliveries in the private sector but only $27.0 \%$ of those in the public sector $(P=0.01)$ and $99.5 \%$ of maternity cases seen in the private sector but only 93.1\% of those seen in the public sector were admitted during daytime workhours $(P=0.003$; Table 2$)$.

\section{Care quality by sector}

Table 3 shows the quality of care by sector - in terms of each of the clinical practices measured. In the overall provision of obstetric care, in both sectors, monitoring of labour using a partograph (1.7\%), screening for pre-eclampsia or eclampsia $(2.3 \%)$, woman-centred care (3.5\%), avoidance of harmful and/or unnecessary interventions (4.3\%) and the active management of the third stage of labour $(24.5 \%)$ were relatively rare whereas measures for the prevention of maternal infection during admission (76.4\%) and health worker avoidance of behaviours harmful to the mothers (74.2\%) were common. In the provision of obstetric care, assessment of maternal blood loss $(P=0.01)$, measures for the prevention of maternal infection during childbirth $(P=0.05)$ and partograph use $(P<0.001)$ were observed significantly more frequently in the private sector than in the public sector.
In the provision of fetal or neonatal care across both sectors, assessment of Apgar scores one and five minutes after birth $(0.9 \%)$, assessment of fetal presentation and fundal height (1.1\%) and the regular monitoring of fetal heart rate $(20.1 \%)$ were rare whereas resuscitation preparedness $(68.1 \%)$, sterile cord care (95.2\%) and support for early initiation of breastfeeding $(69.8 \%)$ were relatively common. One clinical practice - the regular monitoring of fetal heart rate - was observed much more frequently in the private sector than in the public sector $(73.3 \%$ vs $6.6 \% ; P<0.001)$. Observational data disaggregated by each of the 42 items of care that were observed are available from the corresponding author.

Quality of essential care during labour and childbirth was found to be deficient (mean: 35.7\%) across our entire sample of facilities (Table 3 ). Overall, $45.0 \%$ of recommended clinical practices were completed among women giving birth in the private sector compared with $33.3 \%$ in the public sector $(P=0.01)$. Private-sector clients received $40.0 \%$ of the recommended obstetric care practices and $51.0 \%$ of the recommended neonatal care practices - compared with $28.3 \%(P=0.01)$ and $39.0 \%(P=0.02)$, respectively, in the public sector.

The results from the multivariate analysis revealed that, after controlling for confounders, the overall quality of care score was six percentage points higher $(P=0.03)$ in the private sector than in the public sector (Table 4 ). We found no association between use of qualified personnel, facility caseload or the woman's age, caste, parity, referral status or socioeconomic status and the overall quality of care at the time of birth. However, compared with admission on a weekday, admission during the weekends was associated with a quality of care score that was three percentage points lower $(P=0.03)$.

When we examined adjusted variances, for quality of care, between health workers, we found greater variation within health workers (standard deviation, SD: 0.004$)$ than between them (SD: 0.002; intraclass correlation: 0.33). Similarly, there was greater variation, for quality of care, within health facilities (SD: 0.005) than between them (SD: 0.002; intraclass correlation: 0.27$)$. We found no evidence that birth attendants were exerting more - or less - effort sim- 
ply because they were being observed and there was, therefore, no significant Hawthorne effect (available from the corresponding author).

\section{Discussion}

Using clinical observations, we found that, in Uttar Pradesh, essential care provided to women and their neonates - during labour and childbirth - was generally of poor quality. The private facilities generally outperformed the public facilities in terms of both obstetric and neonatal care. Measures to prevent some major causes of maternal mortality - e.g. haemorrhage, hypertensive disorders and sepsis - were rare in both the private and public sectors.

Our study advances the descriptive evidence base on quality of care at the time of birth in India - particularly for the private sector, which has an increasing share of the market for maternity care. ${ }^{18}$ Direct observations of clinical practices offer advantages over other methods of quality assessment, especially when - as in our study - there is no evidence of a Hawthorne effect. We developed a comprehensive measure of quality of care that included adherence to evidence-based guidelines, respectful care practices, harmful and unnecessary interventions and harmful health worker behaviours. The methods we used to calculate separate indices for neonatal care, obstetric care and overall essential care at birth could be used for monitoring quality of care in other settings.

Our multivariate analysis confirmed that, in our study districts, private maternity facilities generally provided a higher standard of care than those in the public sector and that the quality of care provided - in either sector - was not significantly related to the investigated characteristics of the birth attendant, facility or the woman's age, caste, parity, referral status or socioeconomic status. However, compared with admission at other times, admission at a weekend was associated with poorer quality of care. Other studies have also revealed poorer neonatal and obstetric care during weekends than at other times. ${ }^{41,42}$

Care during labour and childbirth in the public sector was less likely to be provided by qualified staff than such care in the private sector. However, we did not find that care provided by qualified personnel was significantly better than that provided by unqualified personnel. Even qualified birth attendants may not be adequately skilled. ${ }^{25,43}$ In a study from India using standardized patients, only minor differences were found between the quality of care given by trained providers and that given by untrained providers - although this study did not focus on maternal and neonatal care. ${ }^{44}$

We did not find any relationship between facility size and quality of care at birth - perhaps because our observa- tions were limited to uncomplicated vaginal births and quality of care for such births was generally poor irrespective of the facility caseload. Previous studies have found a relatively better quality of care at large high-level facilities and this may explain why patients may sometimes bypass small low-level facilities. ${ }^{7}$ Although, we do not have robust evidence on the factors influencing quality of care at maternity facilities in India, evidence from low-income coun-

\section{Table 4. Investigation of the association between the index for the quality of essential care at birth and the characteristics of the birth attendants, maternity facilities and mothers, Uttar Pradesh, India, 2015}

\begin{tabular}{|c|c|c|}
\hline Explanatory variable & Coefficient ${ }^{\mathrm{a}}(95 \% \mathrm{Cl})$ & $P$ \\
\hline Characteristics of birth attendant & & 0.61 \\
\hline Unqualified & Base & \\
\hline Qualified & $0.01(-0.02$ to 0.04$)$ & \\
\hline \multicolumn{3}{|l|}{ Characteristics of facility } \\
\hline Facility sector & & 0.03 \\
\hline Public & Base & \\
\hline Private & 0.06 (0.01 to 0.11$)$ & \\
\hline No. of deliveries at facility in 2014 & & 0.77 \\
\hline$<2000$ & Base & \\
\hline 2000 to 2999 & $0.01(-0.05$ to 0.06$)$ & \\
\hline$\geq 3000$ & $-0.02(-0.08$ to 0.05$)$ & \\
\hline \multicolumn{3}{|l|}{ Characteristics of mother } \\
\hline Day of admission & & 0.03 \\
\hline Weekday & Base & \\
\hline Saturday or Sunday & $-0.03(-0.06$ to 0.003$)$ & \\
\hline Age in years & & 0.91 \\
\hline$<20$ & Base & \\
\hline 21 to 34 & $0.01(-0.04$ to 0.05$)$ & \\
\hline$\geq 35$ & 0.01 ( -0.05 to 0.08$)$ & \\
\hline Parity & & 0.22 \\
\hline Primipara & Base & \\
\hline Multipara & 0.01 (-0.01 to 0.03$)$ & \\
\hline Referral status & & 0.84 \\
\hline Came directly to study facility & Base & \\
\hline Referred from another facility & $0.00(-0.04$ to 0.03$)$ & \\
\hline Caste & & 0.15 \\
\hline Scheduled caste or scheduled tribe & Base & \\
\hline Other backward caste & $0.02(-0.01$ to 0.04$)$ & \\
\hline General caste & 0.03 (0.00 to 0.06$)$ & \\
\hline Wealth quintile & & 0.08 \\
\hline First (poorest) & Base & \\
\hline Second & $0.00(-0.03$ to 0.03$)$ & \\
\hline Third & $0.00(-0.03$ to 0.03$)$ & \\
\hline Fourth & $0.00(-0.03$ to 0.03$)$ & \\
\hline Fifth & 0.04 (0.00 to 0.07 ) & \\
\hline Timing of admission & & 0.62 \\
\hline Within daytime work-hours ${ }^{b}$ & Base & \\
\hline Out of hours & $-0.01(-0.05$ to 0.03$)$ & \\
\hline
\end{tabular}

$\mathrm{Cl}$ : confidence interval.

a Results from a multilevel mixed-effects linear regression.

b That is, between 09:00 and 17:00. 
tries indicates that provider effort could be a key determinant. ${ }^{45}$ Evidence also exists that the private sector generally provides better quality of care because it has superior management and operational systems - including better incentive schemes that attract more motivated and better qualified staff. ${ }^{44}$

Our findings are similar to those of some other studies in India. In a study based in Rajasthan, partograph use was found to be especially weak and monitoring was found often to consist only of repeated unhygienic vaginal examinations. ${ }^{24}$ We found active management of the third stage of labour to be more common in the facilities we surveyed than reported in some neighbouring districts of Uttar Pradesh. ${ }^{23}$ We found respectful rights-based maternity care ${ }^{38}$ to be rare. Our informal observations during data collection - of labour room environments that often appeared chaotic and of some health workers that could be abusive, dominating and threatening on occasions (available from the corresponding author) - were consistent with those previously found in Madhya Pradhesh ${ }^{46}$ and Rajasthan. ${ }^{25}$ Inadequate knowledge and skills, lack of enabling environments, limited supportive supervision, staffing shortages and the poor quality of in-service training could all be underlying causes of the generally poor quality of maternity care in India. ${ }^{24,46}$ The Indian government is currently implementing a range of schemes to improve the quality of intrapartum and immediate postpartum care. ${ }^{47}$ Given the shortages of skilled human resources for maternity care in India, focused efforts to establish a professional cadre of midwives could be beneficial. We found greater variance in quality of care within individual health workers than between them. This could indicate that health workers do not follow standard protocols and/or provide preferential care.

Our study had several limitations. First, there may have been observer bias - e.g. due to the general perception that the private sector is superior because it has better infrastructure and better trained personnel. Second, there were challenges in sampling the private sector. Not only did 13 private facilities refuse to participate but also we had no official sampling frame from which to select private facilities. It is possible that the quality of care provided by the participating private facilities was different to that provided by the other private facilities in Uttar Pradesh. Third, although it provided useful summary measures, our aggregation of numerous indicators into broader indices will have masked variation between individual indicators. Also, in developing our aggregate measures of quality, we gave equal weight to each indicator because there was no scientific basis for applying intervention-specific weights. All of the women who were invited to participate in the study agreed to participate and, by following a strict case-definition, we hoped to minimize any selection bias at participant level. To limit subjectivity, our observers were well trained and used a structured questionnaire to record their observations.

Our findings have at least three key implications. First, a systematic effort to measure and identify existing quality gaps during labour and childbirth, is warranted, especially in India's highburden states. Such research should include private-sector facilities, which provide a substantial and increasing proportion of the maternity care in India. Second, the reasons for the high prevalence of maternity care provided by untrained personnel and the widespread non-adherence to recommended protocols should be investigated further. Third, tailored quality-improvement initiatives ${ }^{48}$ must be designed for facilities in both sectors - with the regular auditing of the actual processes of care linked to functional accountability mechanisms.

\section{Acknowledgements}

We thank the adult participants, their families, health providers, the data collection team at Sambodhi Research and Communications and Pathfinder International and World Health Partners in Uttar Pradesh, India.

Funding: The activities in this manuscript were supported by funding from MSD - an initiative of Merck \& Co, Inc. (Kenilworth, United States of America) - through its MSD for Mothers programme.

Competing interests: None declared.

$$
\begin{aligned}
& \text { ملخودة الرعاية الروتينية الضرورية أثناء الولادة: الملاحظات السريرية لعمليات الولادة غير المعقدة }
\end{aligned}
$$

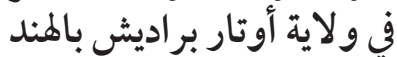




\section{摘要 \\ 目的 旨在评估印度北方邦地区妇产机构的顺产及正常 分婏期基本护理质量。 \\ 方法 2015 年 5 月 26 日至 7 月 8 日, 我们采用临床观 察法对为 26 家医院的 275 对母婴提供的护理进行了 评估。期间采集了 42 项护理数据、总结出 17 项临床 实践和三项综合得分, 然后加权计算出基于人口的估 计值。我们审查了公立和私立机构之间护理质量的未 调整差异。然后采用多级线性混合效应模型来根据接 生员、机构以及产妇特征进行调整。 \\ 结果 我们观察到的私立和公立机构的护理质量均 普遍较差; 每位产妇完成基础临床护理的平均比}

分婏期常规基本护理质量 : 对印度北方邦地区顺利分婏状况的临床观察
例为 $35.7 \%$ 。加权估计值表明，公立和私立机构 由不具备资格的人员提供护理的母婴对比例分别 为 $73.0 \%$ 和 $27.0 \%$; 私立机构提供的产妇、新生儿以 及整体分娩护理优于公立机构。在调整后分析中, 私 立机构整体护理质量得分比公立机构对应得分高出六 个百分点。

结论 2015 年, 妇产机构提供生产和分娩护理的人员经 常不具备资格, 并且在遵守护理规程方面表现整体较 差。北方邦地区的私立和公立机构需要制定相应措施 以衡量和提升生产及分婏期护理质量。

\section{Résumé}

\section{Qualité des soins essentiels de routine à l'accouchement et à la naissance: observations cliniques des naissances sans complications dans l'Uttar Pradesh (Inde)}

Objectif Évaluer la qualité des soins essentiels dispensés lors des accouchements et des naissances sans complications, dans des centres de maternité de l'Uttar Pradesh, en Inde.

Méthodes Entre le 26 mai et le 8 juillet 2015, nous avons réalisé des observations cliniques pour évaluer les soins dispensés à 275 paires mère/nouveau-né, dans 26 hôpitaux. Des données portant sur 42 soins ont été compilées et synthétisées dans 17 catégories de pratiques cliniques et trois scores globaux, puis pondérées pour obtenir des estimations en population. Nous avons examiné les différences de qualité, avant ajustement, entre les établissements publics et privés. Des modèles linéaires multiniveaux à effets mixtes ont été utilisés afin d'ajuster les données pour tenir compte des caractéristiques des accoucheurs, des centres de maternité et des mères.

Résultats La qualité des soins que nous avons observés a généralement été médiocre, autant dans le public que dans le privé; le pourcentage moyen de réalisation des soins cliniques essentiels pour chaque femme

étant de 35,7\%. Les estimations pondérées indiquent que les soins ont été dispensés par du personnel non qualifié dans 73,0\% des cas dans les centres publics et dans 27,0\% des cas dans les centres privés. Les soins obstétricaux, néonataux et les soins d'ordre général dispensés à la naissance ont semblé de meilleure qualité dans les centres privés que dans les centres publics. Dans notre analyse après ajustement, le score pour la qualité générale des soins dispensés a été supérieur de six points de pourcentage dans les centres privés par rapport aux centres publics. Conclusion En 2015, dans les centres de maternité, les soins dispensés lors des accouchements et des naissances ont été réalisés par un personnel souvent non qualifié, et le respect des protocoles de soins s'est généralement avéré médiocre. Des initiatives pour mesurer et améliorer la qualité des soins dispensés lors des accouchements et des naissances doivent être développées dans les centres publics et privés de l'Uttar Pradesh.

\section{Резюме}

\section{Качество оказания основной медицинской помощи во время родов: клинические наблюдения за неосложненными родами в штате Уттар-Прадеш, Индия}

Цель Оценить качество оказания основной медицинской помощи при нормальных родах в родовспомогательных учреждениях штата Уттар-Прадеш, Индия.

Методы Для оценки оказания медицинской помощи авторы использовали клинические наблюдения 275 пар «матьноворожденный», проведенные в период с 26 мая по 8 июля 2015 года в 26 больницах. Были собраны данные о качестве оказания медицинской помощи по 42 пунктам, которые были обобщены и представлены в виде 17 клинических практик и трех суммарных оценок, а затем взвешены для получения оценок на основе популяции. Авторы исследовали нескорректированные различия в качестве между государственными и частными медицинскими учреждениями.Дляучетахарактеристикакушеров, медицинских учреждений и матерей были использованы многоуровневые линейные модели смешанных эффектов.

Результаты Наблюдаемое качество оказания медицинской помощивцеломбылонизким какв частных,таки вгосударственных медицинскихучреждениях; средняя доля основных клинических процедур, выполненных для каждой женщины, составила
35,7\%. Взвешенные оценки показывают, что медицинскую помощь оказывал неквалифицированный персонал для 73,0 и 27,0\% пар «мать-новорожденный» в государственных и частных учреждениях соответственно. Было обнаружено, что качество акушерской, неонатальной и общей медицинской помощи при родовспоможении было выше в частных медицинских учреждениях, чем в государственных. В скорректированном анализе оценка общего качества оказания медицинской помощи в частных учреждениях была на шесть процентных пунктов выше, чем соответствующая оценка для государственных учреждений. вывод В 2015 году персонал, оказывающий медицинские услуги при родах в родовспомогательных учреждениях, часто был неквалифицированным и соблюдение протоколов по медицинскому уходу было, как правило, неудовлетворительным. В частных и государственных учреждениях в штате Уттар-Прадеш требуется разработка инициатив по измерению и повышению качества оказания медицинской помощи во время родов. 


\section{Resumen}

\section{Calidad de la atención esencial rutinaria durante el parto: observaciones clínicas de nacimientos sin complicaciones en Uttar} Pradesh, India

Objetivo Evaluar la calidad de la atención esencial durante partos y nacimientos normales en maternidades de Uttar Pradesh, India.

Métodos Entre el 26 de mayo y el 8 de julio de 2015, se utilizaron observaciones clínicas para evaluar la prestación de asistencia a 275 pares madre-neonato en 26 hospitales. Se recopiló información sobre 42 elementos de la atención, resumidos en 17 prácticas clínicas y tres puntuaciones genéricas, y se ponderaron para obtener estimaciones basadas en la población. Se examinaron las diferencias no ajustadas de la atención entre los centros públicos y los privados. Se utilizaron modelos lineales de efectos mixtos en varios niveles para ajustar las características de los asistentes de parto, los centros y las madres.

Resultados En general, la calidad de la atención observada fue pobre, tanto en los centros públicos como en los privados. El porcentaje medio de las prácticas de atención clínica esencial completadas para cada mujer fue del $35,7 \%$. Las estimaciones ponderadas indican que la

atención fue proporcionada por personal no cualificado para el 73,0\% y el $27,0 \%$ de los pares madre-neonato en centros públicos y privados respectivamente. La atención obstétrica, la atención neonatal y la atención general tras el nacimiento parecieron ser mejor en centros privados que en públicos. En el análisis ajustado, la puntuación para la calidad general de la atención en los centros privados resultó estar seis puntos porcentuales por encima de la puntuación correspondiente a los centros públicos.

Conclusión En 2015, el personal que proporcionaba atención de parto y nacimiento en maternidades solía carecer de cualificación, y su adherencia a los protocolos de atención era, en general, escasa. Las iniciativas para medir y mejorar la calidad de la atención durante el parto y el nacimiento necesitan desarrollarse en los centros públicos y privados de Uttar Pradesh.

\section{References}

1. The World Health Report: 2005: make every mother and child count. Geneva: World Health Organization; 2005. Available from: http://www.who. int/whr/2005/whr2005_en.pdf [cited 2017 Mar 22].

2. Sharma G, Mathai M, Dickson KE, Weeks A, Hofmeyr G, Lavender T, et al. Quality care during labour and birth: a multi-country analysis of health system bottlenecks and potential solutions. BMC Pregnancy Childbirth. 2015;15(S2) Suppl 2:S2. doi: http://dx.doi.org/10.1186/1471-2393-15-S2-S2 PMID: 26390886

3. Lawn JE, Blencowe H, Oza S, You D, Lee AC, Waiswa P, et al.; Lancet Every Newborn Study Group. Every newborn: progress, priorities, and potential beyond survival. Lancet. 2014 Jul 12;384(9938):189-205. doi: http://dx.doi. org/10.1016/S0140-6736(14)60496-7 PMID: 24853593

4. UNICEF data: monitoring the situation of children and women [Internet]. New York: United Nations Children's Fund; 2016. Available from: https:// data.unicef.org/ [cited 2017 Mar 22].

5. Hinderaker SG, Olsen BE, Bergsjø PB, Gasheka P, Lie RT, Havnen J, et al. Avoidable stillbirths and neonatal deaths in rural Tanzania. BJOG. 2003 Jun;110(6):616-23. doi: http://dx.doi.org/10.1046/j.1471-0528.2003.02153.x PMID: 12798482

6. Abouchadi S, Alaoui AB, Meski FZ, Bezad R, De Brouwere V. Preventable maternal mortality in Morocco: the role of hospitals. Trop Med Int Health. 2013 Apr;18(4):444-50. doi: http://dx.doi.org/10.1111/tmi.12065 PMID: 23360349

7. Kruk ME, Mbaruku G, McCord CW, Moran M, Rockers PC, Galea S. Bypassing primary care facilities for childbirth: a population-based study in rural Tanzania. Health Policy Plan. 2009 Jul;24(4):279-88. doi: http://dx.doi org/10.1093/heapol/czp011 PMID: 19304785

8. Parkhurst JO, Ssengooba F. Assessing access barriers to maternal health care: measuring bypassing to identify health centre needs in rural Uganda. Health Policy Plan. 2009 Sep;24(5):377-84. doi: http://dx.doi.org/10.1093/ heapol/czp023 PMID: 19520736

9. Care in normal birth: a practical guide. Geneva: World Health Organization; 1996

10. Laopaiboon M, Lumbiganon P, McDonald SJ, Henderson-Smart DJ, Green S, Crowther CA; SEA-ORCHID Study Group. Use of evidence-based practices in pregnancy and childbirth: South East Asia Optimising Reproductive and Child Health in Developing Countries project. PLoS ONE. $2008 \mathrm{Jul}$ 09;3(7):e2646. doi: http://dx.doi.org/10.1371/journal.pone.0002646 PMID: 18612381

11. Sandin-Bojö A-K, Kvist LJ. Care in labor: a Swedish survey using the Bologna score. Birth. 2008 Dec;35(4):321-8. doi: http://dx.doi.org/10.1111/j.1523536X.2008.00259.x PMID: 19036045

12. Khalil K, Sholkamy H, Hassanein N, Cherine M, Elnoury A, Mohsen L, et al.; Choices and Challenges in Changing Childbirth Research Network. Routines in facility-based maternity care: evidence from the Arab world. BJOG. 2005 Sep;112(9):1270-6. doi: http://dx.doi.org/10.1111/j.1471-0528.2005.00710.x PMID: 16101607

13. Rowe AK, de Savigny D, Lanata CF, Victora CG. How can we achieve and maintain high-quality performance of health workers in low-resource settings? Lancet. 2005 Sep 17-23;366(9490):1026-35. doi: http://dx.doi. org/10.1016/S0140-6736(05)67028-6 PMID: 16168785

14. Strategies for assisting health workers to modify and improve skills: developing quality health care - a process of change. Geneva: World Health Organization; 2000. Available from: http://www.who.int/hrh/documents/ en/improve_skills.pdf [cited 2017 Mar 22].

15. Trends in maternal mortality: 1990 to 2015: estimates by WHO, UNICEF, UNFPA. World Bank Group and the United Nations Population Division. Geneva: World Health Organization; 2015. Available from: http://apps.who. int/iris/bitstream/10665/194254/1/9789241565141_eng.pdf?ua=1 [cited 2017 Mar 20].

16. The Global Strategy for Women's. Children's and Adolescents' Health (20162030). Washington: Every Woman Every Child, 2015. Available from: http://www. who.int/pmnch/media/events/2015/gs_2016_30.pdf [cited 2017 Mar 20].

17. Maternal and newborn health toolkit. New Delhi: Maternal Health Division, Government of India; 2013.

18. Campbell OM, Benova L, MacLeod D, Baggaley RF, Rodrigues LC, Hanson K, et al. Family planning, antenatal and delivery care: cross-sectional survey evidence on levels of coverage and inequalities by public and private sector in 57 low- and middle-income countries. Trop Med Int Health. 2016 Apr;21(4):486-503. doi: http://dx.doi.org/10.1111/tmi.12681 PMID: 26892335

19. Pomeroy AM, Koblinsky M, Alva S. Who gives birth in private facilities in Asia? A look at six countries. Health Policy Plan. 2014 Jul;29 Suppl 1:i38-47. doi: http://dx.doi.org/10.1093/heapol/czt103 PMID: 25012797

20. Thind A, Mohani A, Banerjee K, Hagigi F. Where to deliver? Analysis of choice of delivery location from a national survey in India. BMC Public Health. 2008 Jan 24;8(1):29. doi: http://dx.doi.org/10.1186/1471-2458-8-29 PMID: 18218093

21. Singh A, Mavalankar DV, Bhat R, Desai A, Patel SR, Singh PV, et al. Providing skilled birth attendants and emergency obstetric care to the poor through partnership with private sector obstetricians in Gujarat, India. Bull World Health Organ. 2009 Dec;87(12):960-4. doi: http://dx.doi.org/10.2471/ BLT.08.060228 PMID: 20454488

22. Evans CL, Maine D, McCloskey L, Feeley FG, Sanghvi H. Where there is no obstetrician - increasing capacity for emergency obstetric care in rural India: an evaluation of a pilot program to train general doctors. Int J Gynaecol Obstet. 2009 Dec;107(3):277-82. doi: http://dx.doi.org/10.1016/j. ijgo.2009.09.006 PMID: 19846091

23. Stanton CK, Deepak NN, Mallapur AA, Katageri GM, Mullany LC, Koski A, et al. Direct observation of uterotonic drug use at public health facilitybased deliveries in four districts in India. Int J Gynaecol Obstet. 2014 Oct;127(1):25-30. doi: http://dx.doi.org/10.1016/j.ijgo.2014.04.014 PMID: 25026891 
24. Iyengar K, Jain M, Thomas S, Dashora K, Liu W, Saini P, et al. Adherence to evidence based care practices for childbirth before and after a quality improvement intervention in health facilities of Rajasthan, India. BMC Pregnancy Childbirth. 2014 Aug 13;14(1):270. doi: http://dx.doi. org/10.1186/1471-2393-14-270 PMID: 25117856

25. Iyengar SD, lyengar K, Martines JC, Dashora K, Deora KK. Childbirth practices in rural Rajasthan, India: implications for neonatal health and survival. J Perinatol. 2008 Dec;28 Suppl 2:S23-30. doi: http://dx.doi.org/10.1038/ jp.2008.174 PMID: 19057565

26. Neuman M, Alcock G, Azad K, Kuddus A, Osrin D, More NS, et al. Prevalence and determinants of caesarean section in private and public health facilities in underserved South Asian communities: cross-sectional analysis of data from Bangladesh, India and Nepal. BMJ Open. 2014 Dec 30;4(12):e005982. doi: http://dx.doi.org/10.1136/bmjopen-2014-005982 PMID: 25550293

27. Potter JE, Berquó E, Perpétuo IH, Leal OF, Hopkins K, Souza MR, et al. Unwanted caesarean sections among public and private patients in Brazil: prospective study. BMJ. 2001 Nov 17;323(7322):1155-8. doi: http://dx.doi. org/10.1136/bmj.323.7322.1155 PMID: 11711406

28. Sharma G. The changing paradigm of labour and childbirth in Indian cities: an enquiry into increasing rates of caesarean deliveries. Int J Epidemiol. 2016 Oct;45(5):1390-3. doi: http://dx.doi.org/10.1093/ije/dyw119 PMID: 27313165

29. Murray SF, Hunter BM, Bisht R, Ensor T, Bick D. Effects of demand-side financing on utilisation, experiences and outcomes of maternity care in low- and middle-income countries: a systematic review. BMC Pregnancy Childbirth. 2014; Jan 17;14(1):30. doi: http://dx.doi.org/10.1186/1471-239314-30 PMID: 24438560

30. Pereira SK, Kumar P, Dutt V, Haldar K, Penn-Kekana L, Santos A, et al. Protoco for the evaluation of a social franchising model to improve maternal health in Uttar Pradesh, India. Implement Sci. 2015 May 26;10(1):77. doi: http:// dx.doi.org/10.1186/s13012-015-0269-2 PMID: 26008202

31. Annual Health Survey 2012-2013. Fact sheet. Uttar Pradesh. New Delhi: Office of the Registrar General \& Census Commissioner; 2013. Available from: http://www.censusindia.gov.in/vital_statistics/AHSBulletins/ AHS_Factsheets_2012-13/FACTSHEET-UTTAR_PRADESH.pdf [cited 2017 Mar 22]

32. Health management information system [Internet]. New Delhi: Ministry of Health and Family Welfare; 2015. Available from: https://nrhm-mis.nic.in [cited 2015 Dec 20].

33. Getachew A, Ricca J, Cantor D, Rawlins B, Rosen H, Tekleberhan A, et al. Quality of care for prevention and management of common maternal and newborn complications: a study of Ethiopia's hospitals. Baltimore: Jhpiego; 2011.

34. Maternal, newborn, child and adolescent health. Integrated management of pregnancy and childbirth [Internet]. Geneva: World Health Organization; 2017. Available from: http://www.who.int/maternal child adolescent/ topics/maternal/impac/en/ [cited 2017 Mar 20]

35. National Family Health Survey, India. NFHS-4 [Internet]. Mumbai: International Institute for Population Sciences; 2014. Available from: http:// rchiips.org/nfhs/nfhs4.shtml [cited 2017 Mar 22]
36. Donabedian A. The quality of care. How can it be assessed? JAMA 1988 Sep 23-30;260(12):1743-8. doi: http://dx.doi.org/10.1001/ jama.1988.03410120089033 PMID: 3045356

37. Hulton L, Matthews Z, Stones R. A framework for the evaluation of quality of care in maternity services. Soc Sci Med. 2007 May;64(10):2083-95. PMID: 17374551

38. Respectful maternity care: the universal rights of childbearing women. Washington: White Ribbon Alliance; 2012. Available from: http:// whiteribbonalliance.org/wp-content/uploads/2013/10/Final_RMC_Charter. pdf [cited 2016 Dec 4].

39. Vyas S, Kumaranayake L. Constructing socio-economic status indices: how to use principal components analysis. Health Policy Plan. 2006 Nov;21(6):459-68. doi: http://dx.doi.org/10.1093/heapol/czl029 PMID 17030551

40. Snijders TA. Multilevel analysis. In: Lovrić M, editor. International encyclopedia of statistical science. Berlin: Springer; 2011. pp. 879-82. doi: http://dx.doi.org/10.1007/978-3-642-04898-2_387

41. Palmer WL, Bottle A, Aylin P. Association between day of delivery and obstetric outcomes: observational study. BMJ. 2015 Nov 24;351:h5774. doi: http://dx.doi.org/10.1136/bmj.h5774 PMID: 26602245

42. Pasupathy D, Wood AM, Pell JP, Fleming M, Smith GC. Time of birth and risk of neonatal death at term: retrospective cohort study. BMJ. 2010 Jul 15;341 jul15 1:c3498. doi: http://dx.doi.org/10.1136/bmj.c3498 PMID: 20634347

43. Harvey SA, Blandón YCW, McCaw-Binns A, Sandino I, Urbina L, Rodríguez C, et al.; Nicaraguan Maternal and Neonatal Health Quality Improvement Group. Are skilled birth attendants really skilled? A measurement method, some disturbing results and a potential way forward. Bull World Health Organ. 2007 Oct;85(10):783-90. doi: http://dx.doi.org/10.2471/ BLT.06.038455 PMID: 18038060

44. Das J, Holla A, Das V, Mohanan M, Tabak D, Chan B. In urban and rural India, a standardized patient study showed low levels of provider training and huge quality gaps. Health Aff (Millwood). 2012 Dec;31(12):2774-84. doi: http://dx.doi.org/10.1377/hlthaff.2011.1356 PMID: 23213162

45. Berendes S, Heywood P, Oliver S, Garner P. Quality of private and public ambulatory health care in low and middle income countries: systematic review of comparative studies. PLoS Med. 2011 Apr;8(4):e1000433. doi: http://dx.doi.org/10.1371/journal.pmed.1000433 PMID: 21532746

46. Chaturvedi S, De Costa A, Raven J. Does the Janani Suraksha Yojana cash transfer programme to promote facility births in India ensure skilled birth attendance? A qualitative study of intrapartum care in Madhya Pradesh. Glob Health Action. 2015;8(0):27427. doi: http://dx.doi.org/10.3402/gha. v8.27427 PMID: 26160769

47. Achievements under Millennium Development Goals. New Delhi: Ministry of Health and Family Welfare; 2015. Available from: http://pib.nic.in/ newsite/PrintRelease.aspx?relid=123669 [cited 2017 Mar 20].

48. Barker PM, Reid A, Schall MW. A framework for scaling up health interventions: lessons from large-scale improvement initiatives in Africa. Implement Sci. 2016 Jan 29;11(1):12. doi: http://dx.doi.org/10.1186/s13012016-0374-x PMID: 26821910 